\title{
Factors Influencing Out-of-School Youth in Municipality of Clarin, Bohol
}

\author{
Margie P. Vito, M Sc., Alfredo E. Niones, Ph.D., Daisy V. Dellosa, Ph.D.
}

Department of College of Teacher's Education, Bohol Is land State University, Philippines

Email: bisu_clarin@yahoo.com

\begin{abstract}
Out-of-school youth are susceptible population with numerous needs. Many face dim employment and uncertain futures. The youth in this study were those aged 15-30years' old who were not in school and unemployed, underemployed or lacking basic skills. There were five factors that influenced out-of-school youth in this study namely: unaware of free tuition, financial incapacity of parents, difficulty in passing the entrance exam, don't like to go to school and got married early. Among these factors, it was financial incapacity of parents that influenced most. A total of 1118 out-of-school youth were identified in Clarin, Bohol. The result of Chi-square Test of Independence showed that there was a significant difference on all the factors that influenced out-of-school youth. This was evident with the tabular value 43.473 less than the Chi square computed value 2 532.91. Having these results, indeed there is a need to uplift the financial state of the people by providing livelihood projects and scholarships for those who wanted to pursue their studies. Keywords-Adolescence, Education, Financial Instability, Socio-Economic Development
\end{abstract}

\section{INTRODUCTION}

Education of every child is very vital because it is considered as a powerful tool for socio-economic development of a nation. It is the only way of bringing tremendous change to the lives of each individual. Molding characteristics and enhancing knowledge are better ways to expedite the process of national development. It also served as means of establishing planners, policy-makers and other public leaders in the future. And the segment of society that plays an active part in socio-economic development is made up of youth or adolescent.

Institution like Bohol Island State University (BISU) Clarin campus focused on providing quality higher education and is one of the recipients of free tuition fee. Even with the free tuition there were still outof-school-youth in the community based on personal communications of some nearby residents. In this regard, a baseline study was conducted to address the issue.
In this study, several factors were considered. First was the financial incapacity of parents which is a common dilemma. Second was the lack of awareness on the free tuition fee program since there are people who are living in remote areas. Third factor was the fear of failing the entrance exam because a lot of people know that BISU set standards on quality education. Thus, enrollees need to pass the exam before they can enroll on a specific course. Another factor was the insufficient knowledge on major areas of exam like English, Math and Science.

Awareness on the factors that influence out-ofschool youth will be important to create programs that will decrease their number. This will also help the institution to plan extension projects that is relevant to the community. Although, there were already community extension programs of BISU Clarin Campus but no studies were documented distinctively for the College of Teacher's Education (CTE). Thus, there is a need for benchmark study in order to overcome this long undertaking for research development and extension.

\section{RELATED STUDIES}

Out-of-school youth are susceptible population with numerous needs. Many face vague employment and uncertain futures. Out-of-school youth are defined as those youth 16-24 who are not in school and unemployed, underemployed or lacking basic skills (Shrestha, 2007). At present there has been no single system that provides services to out-of-school youth. Many systems can play a role in addressing their problems including public universities, workforce, government sectors and nongovernment agencies. Funding source from these organizations can support to serve out-of-school youth.

In the Philippines, youth, defined as those who are 15 to 30 years old, comprised 30.1 per cent of the total population and nearly half of the country's labour force (NYC, 1998). Currently, 36 million populations aged 624 years were surveyed by Functional Literacy, Education and Mass Media (2015) in which one in every ten or about 4 million Filipino children were out-of-school. Top 
reason of the nearly four million youth was because they entered into union or marriage. Another reason was the insufficient income of the family referring to all educational expenses other than tuition fees. Other reas on was due to their lack of interest in pursuing their studies. This observation here in the Philippines is parallel with the study of Lerman (1997) in United States that marriage was also top reason for out-of-school youth. Most were not poor, but 19 percent lived in families below the poverty line and another 23 percent were in families between the poverty line (Lerman, 1997).

Youth constitute $25 \%$ of the global force but their lack of formal education leads to unemployment. According to Groce(2004), youth unemployment reached a very high record of 88 million worldwide. There was about $85 \%$ of youth living in developing countries in the world that are almost four times unemployed (Alston,2004).

Moreover, one of possible causes is living in remote areas as vast majority of population in the country are living in rural areas and some are in islands. Remoteness of an area could lead to unawareness of residents particularly on programs of free tuition. Same with other developing countries in the world, it was shown that they have invested more on rural areas particularly in literacy, primary education, vocational training and livelihood programs (Shrestha, 2007).

Generally, education is empowerment of people by widening their knowledge and skills (Bray, 1991). United Nations declared education as basic human right five years ago. This is because it is an effective instrument for social and economic development and national integration that is the reason why it was pre-condition for development. In fact, developing countries like Japan focus on human resource development and resulted to 90\% educational improvement (Jones, 1993).

However, third world countries including the Philippines were far behind literacy until few decades. Hence, as an institution (Bohol Island State University) BISU Clarin campus conducted this study to know the factors that influence out-of-school youth and mitigate them in the pursuit of economic development by people literacy.

\section{RESEARCH PROBLEM}

This study aimed to know the factors that hinder youth in Clarin, Bohol to enroll in BISU-Clarin Campus. This study particularly aims to answer the following problems. What are the factors that influence out-of-school youth of not pursuing tertiary education?

Is there a relationship among the factors that influence out-of-school youth?

\section{MATERIALS AND METHODS}

This study was conducted in Municipality of Clarin. This was the $5^{\text {th }}$ class municipality in the province of Bohol located 61 kilometers away from Tagbilaran City. According to the 2015 census it has 20,301 population. It has a land cover of $52.12 \mathrm{~km}^{2}$. It was strategically located at $9^{\circ} 58^{\prime}$ North and $124^{\circ} 01^{\prime}$ East. It is comprised of 24 barangays namely: Poblacion Norte, Poblacion Sur, Poblacion Centro, Tangaran, Bacani, Comaang, Nahawan, Mataob, Cantuyok, Caboy, Bogtongbod, Cabog, Tubod, Danahao, Buangan, Buntod, Katipunan, Lahog, Buacao, Candajec, Bonbon, Caluwasan, Villaflor and Tontunan.

The respondents of this study were all out-ofschool youth within the 24 barangays of Clarin aged 1530 years old. The questions on the survey questionnaire was adopted from Philippine Statistics Authority, 2015. The questions were translated to vernacular language during the survey in order for the respondents to ponder the answers properly.

\section{RESULTS AND DISCUSSIONS}

The factors that influenced out-of-school youth were shown in the Table 1. The main factor that influence outof-school youth was financial incapacity of parents. This could be because farmers and fishermen were predominant in the municipality. Similar result was shown in the study of Adam et al.,2016 in Ghana where poverty caused by unstable income of parents was the main reason of out-of-school youth. Second in rank was unaware of free tuition. This could be due to the fact that most of the residents were in secluded areas.According to Rumberger (2011) people in remote areas are highly isolated and lack of exposure to the community. Third was their no intent of schooling which could be because of the strategic location of BISU-Clarin which is in Poblacion where there are lots of people and is welldeveloped. They may have been affected by such living conditions which together with language barriers, cultural differences, frequent relocating and exposure to prejudice additionally contribute to a high dropout rate (Bowers \&Sprott, 2012; Bynum \& Thompson, 1983; Rumberger, 2011). Fourth was difficulty in passing the entrance exam. This could be because of lack of formal education since some are graduate from alternative learning system. Lastly, got married early which for other countries were the common cause of student attrition. According to UNICEF (1992), 10,000 girls get pregnant every year. The same result was also observed in Kenya where there was an increasing number of youth who got married early (Mumbi, 2009). 
Table.1: Factors that Influencing Out-of-School Youth $(N=1118)$

\begin{tabular}{lccc}
\hline $\begin{array}{l}\text { Factors Influencing Out- } \\
\text { of-School Youth }\end{array}$ & WM & DV & Rank \\
\hline Unaware of free tuition & 2.80 & A & $\mathbf{2}^{\text {nd }}$ \\
\hline $\begin{array}{l}\text { Difficulty in passing the } \\
\text { exam }\end{array}$ & 2.54 & A & $\mathbf{4}^{\text {th }}$ \\
\hline $\begin{array}{l}\text { Financial incapacity of } \\
\text { parents }\end{array}$ & 3.08 & SA & 1st \\
\hline Got married early & 2.43 & A & 5th \\
\hline Don't like to go to school & 2.66 & A & 3rd \\
\hline
\end{tabular}

There was a significant difference among the factors that influence out-of-school youth as shown in Table 2. Chi-square computed value of 2532.91 was way higher compared to tabular value with 43.473 .

Table.2: Chi-Square Test of Factors that Influence Outof-school youth

\begin{tabular}{cclll}
\hline Chi- & $d \boldsymbol{f}$ & $\begin{array}{l}\text { Significan } \\
\text { t Level }\end{array}$ & $\begin{array}{l}\text { Tabular } \\
\text { Value }\end{array}$ & $\begin{array}{l}\text { Interpretat } \\
\text { ion }\end{array}$ \\
$\begin{array}{c}\text { Compuare } \\
\text { d Value }\end{array}$ & & & \\
\hline
\end{tabular}

$\begin{array}{lllll}2532.91 & 27 & 0.05 & 43.473 & \text { Significant }\end{array}$

\section{CONCLUSION}

Out-of-school youth can be caused by several factors but it is mainly influenced by lack of financial capacity of parents. Hence, it is necessary to provide livelihood in each community of Clarin to uplift the lives of people. Bohol Island State University may also help in engaging awareness on the importance of education and instilling that the youth are the hope for the countries development.

\section{ACKNOWLEDGEMENTS}

The researchers would like to thank the funding agency Bohol Island State University Clarin Campus for making this study possible.

\section{REFERENCES}

[1] B.P. Shrestha. 2007.A Study of Socio-Economic of Out of School Youth and Adolescents of Kailali District, Nepal. P.1

[2] National Youth Commission (NYC) (1997a). The Situation of Youth in the Philippines (First National Study).

[3] Lerman, S. 1997. A review of research perspectives on mathematics teacher education.In Making sense of mathematics teacher education (pp. 33-52). Springer Netherlands.

[4] N.E.Groce.2004.Adolescent and Youth Issues and Challenges.Asia Pacific Journal.Vol15.No.2
[5] Alston, P. 2004. 'Core labour standards' and the transformation of the international labour rights regime. European Journal of International Law, 15(3), 457-521.

[6] Bray, M. 1991. Ministries of education in small states: Case studies of organisation and management. Commonwealth Secretariat.

[7] Jones, C. 1993. The pacific challenge. New perspectives on the welfare state in Europe, 198-217.

[8] Rumberger, R. (2011). Dropping Out: Why Students Drop Out of High School and What Can Be Done about It. Cambridge, MA, USA: Harvard University Press.

[9] Bowers, A. J. \&Sprott, R. (2012). Examining the Multiple Trajectories Associated with Dropping Out of High School: A Growth Mixture Model Analysis. The Journal of Educational Research, 105, 176-195.

[10] Bynum, J., \& Thompson, W. (1983). Dropouts, stop outs and persisters: The effects of race and sex composition of college classes. College and University, 59(1), 39-48.

[11] UNICEF (1992). Education sector adjustment credit: Situation analysis. Nairobi: UNICF.

[12] Mumbi, L. (2009).Child Growth and Development. Nairobi: SasaSema publishers. 